\title{
Interactions between photoacidic 3-hydroxy- naphtho[1,2-b]quinolizinium and cucurbit[7]uril: Influence on acidity in the ground and excited state
}

\author{
Jonas Becher, Daria V. Berdnikova, Darinka Dzubiel, Heiko Ihmels* and Phil M. Pithan
}

\author{
Full Research Paper \\ Address: \\ Department of Chemistry and Biology, University of Siegen and \\ Center of Micro- and Nanochemistry and Engineering, \\ Adolf-Reichwein-Str. 2, 57068 Siegen, Germany \\ Email: \\ Heiko Ihmels* - ihmels@chemie.uni-siegen.de \\ * Corresponding author \\ Keywords: \\ azoniahetarenes; cucurbit[7]uril; heterocycles; photoacids; \\ supramolecular photochemistry
}

Beilstein J. Org. Chem. 2017, 13, 203-212.

doi:10.3762/bjoc. 13.23

Received: 17 October 2016

Accepted: 16 January 2017

Published: 01 February 2017

Associate Editor: T. J. J. Müller

(c) 2017 Becher et al.; licensee Beilstein-Institut.

License and terms: see end of document.

\begin{abstract}
3-Hydroxynaphtho[1,2-b]quinolizinium was synthesized by cyclodehydration route and its optical properties in different media were investigated. The absorption and emission spectra of this compound depend on the $\mathrm{pH}$ of the solution. Thus, at higher $\mathrm{pH}$ values the deprotonation yields a merocyanine-type dye that exhibits significantly red-shifted absorption bands and causes a dual emisson, i.e., a combination of emission bands of the hydroxyquinolizinium and its deprotonated form. Whereas this compound is a weak acid in the ground state $\left(\mathrm{p} K_{\mathrm{a}}=7.9\right)$, it has a strongly increased acidity in the excited state $\left(\mathrm{p} K_{\mathrm{a}}{ }^{*}=0.4\right)$. As a result, the blueshifted fluorescence of the hydroxyquinolizinium becomes dominant only under strongly acidic conditions. In addition, it is shown that 3-hydroxynaphtho[1,2-b] quinolizinium binds to cucurbit[7]uril (CB[7]) with moderate affinity $\left(K_{\mathrm{b}}=1.8 \times 10^{4} \mathrm{M}^{-1}, \mathrm{pH}^{5}\right)$ and that the $\mathrm{p} K_{\mathrm{a}}$ and $\mathrm{p} K_{\mathrm{a}}{ }^{*}$ values of this ligand increase by about two to three orders of magnitude, respectively, when bound to CB[7].
\end{abstract}

\section{Introduction}

The complexation of ligands by macrocyclic host molecules, such as crown ethers, cyclodextrins, calixarenes or cucurbiturils, usually has a significant influence on their chemical and physicochemical properties [1,2]. Among the most efficient and versatile host systems along these lines are cucurbit $[n]$ urils $(\mathrm{CB}[n])[3-5]$, that consist of methylene-linked glycoluril units that create a hydrophobic, barrel-type container structure.
Depending on the number of monomeric units, $n$, this host system is available with different diameters (from $\mathrm{CB}[5]$ : $450 \mathrm{pm}$ to $\mathrm{CB}[10]: 1.3 \mathrm{~nm}$ ); and it was demonstrated in numerous studies that a plethora of different organic ligands exists that associate with $\mathrm{CB}[n]$ hosts with high affinity [6]. In most cases, this complexation strongly affects the chemical or physical properties of the ligand. For example, it was demonstrated 
that the optical properties of organic dyes may be modified drastically upon complexation in the $\mathrm{CB}$ cavity [7]. At the same time, this effect of the ligand- $\mathrm{CB}[n]$ interplay may be used to modify and control the photochemical properties of a guest molecule $[8,9]$. For instance, the encapsulation of photoactive molecules in the constrained medium of a cucurbituril cavity enables the performance of chemo-, regio- or stereoselective photoreactions that are not possible in homogeneous solution [10-15].

Considering the importance of acid-base equilibria in chemistry and biology it is also tempting to employ the reversible complexation of acidic or alkaline guest molecules with $\mathrm{CB}[n]$ for the controlled modification of their acidity or basicity. In fact, it was shown that the $\mathrm{p} K_{\mathrm{a}}$ of organic acids and bases often shifts by orders of magnitude upon association with $\mathrm{CB}[n][16-$ 24], which may be used, e.g., to modify catalytic activity [6] or for sensing purposes [7]. Notably, the same effect was observed for the excited-state proton transfer (ESPT) of so-called photoacids. The latter are weak acids in the ground state, whereas their acidity in the excited state increases significantly [2527]. As the activity of photoacids is triggered by light, they have a great potential to be employed as proton sources with high local and temporal control. In this context, it was shown that the excited state acidity of organic photoacids such as topotecan, pyrrolylphenylpyridine, hydroxyacetonaphthone, or hydroxybenzimidazole changes considerably on complexation with cucurbiturils [28-34]. The change of acidity, however, depends on the actual complex structure. For example, it was demonstrated in a comparative study of 2-naphthol and a hydroxyflavylium derivative that the ESPT is suppressed upon complexation with $\mathrm{CB}$ [7] if the hydroxy functionality is embedded deeply in the host cavity. In contrast, if the hydroxy group of the ligand points far outside the binding pocket of $\mathrm{CB}$ [7] the ESPT is comparable to the one observed with the noncomplexed ligand [28].

Recently, we discovered that the 8-hydroxybenzo[b]quinolizinium ion (1a, Figure 1) represents an efficient water-soluble photoacid $\left(\mathrm{p} K_{\mathrm{a}}=7.2 ; \mathrm{p} K_{\mathrm{a}}{ }^{*}<0\right)$ [35]. Furthermore, it was observed that quinolizinium derivatives $\mathbf{1 b}$ and $\mathbf{1 c}$ bind to

cucurbiturils with high affinity [36,37]. Therefore, it seemed possible that the available range of $\mathrm{p} K_{\mathrm{a}}$ and $\mathrm{p} K_{\mathrm{a}}{ }^{*}$ values of this class of compounds can be extended by complexation with an appropriately sized $\mathrm{CB}[n]$. To test this hypothesis we synthesized 3-hydroxynaphtho[1,2-b]quinolizinium (2, Figure 1) and studied its prototropic equilibria in the ground and excited state along with the influence of $\mathrm{CB}[7]$ on its acidity. We chose the naphthoquinolizinium chromophore because of its positive charge providing ion-dipole interactions with the carbonyl portals of $\mathrm{CB}[7]$ as well as its extended $\pi$ system, that was proposed to cause a higher affinity to the $\mathrm{CB}$ [7] due to an increased hydrophobic effect. Moreover, the naphthoquinolizinium ion resembles the quinolizinium-type alkaloids palmatine, berberine and coptisine, which were also shown to bind to $\mathrm{CB}[7]$ [38-40] and may thus serve as an appropriate comparison.<smiles>[R]c1cc2cc3cccc[n+]3cc2cc1[R]</smiles>

1a: $\mathrm{R}^{1}=\mathrm{OH}, \mathrm{R}^{2}=\mathrm{H}$

1b: $R^{1}=R^{2}=H$

1c: $R^{1}=H, R^{2}=\mathrm{NH}_{2}$

Figure 1: Structures of quinolizinium derivatives $\mathbf{1 a - c}$ and $\mathbf{2}$.

\section{Results}

\section{Synthesis}

Hydroxynaphthoquinolizinium 2 was synthesized by the established cyclodehydration route (Scheme 1) [41,42]. Thus, the quaternization of 2-(1,3-dioxolan-2-yl)pyridine (3) [43] with 2-methoxy-6-bromomethylnaphthalene (4) [44] gave the corresponding (naphthylmethyl)pyridinium bromide 5 in $62 \%$ yield. Subsequent treatment of this intermediate with aq $\mathrm{HBr}(48 \%)$ led to acid-catalyzed cyclization and elimination of water, as well as to demethylation of the ether group, to give 3-hydroxynaphtho[1,2-b]quinolizinium bromide (2) in $49 \%$ yield. The new compounds $\mathbf{2}$ and $\mathbf{5}$ were identified and characterized by 1D- und 2D-NMR spectroscopy, mass spectrometry and elemental analysis.<smiles>c1ccc(C2OCC[OH+]2)nc1</smiles>

3<smiles>COc1ccc2cc(CBr)ccc2c1</smiles>

4

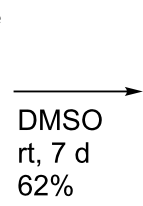

$62 \%$<smiles>COc1ccc2cc(C[n+]3ccccc3C3OCCO3)ccc2c1</smiles>

5
$\frac{\mathrm{HB}}{\mathrm{H}_{2} \mathrm{O}}$

$49 \%$<smiles></smiles> 


\section{Absorption and emission properties}

The absorption and emission properties of naphthoquinolizinium derivative $\mathbf{2}$ were determined in representative proticpolar $\left(\mathrm{H}_{2} \mathrm{O}, \mathrm{MeOH}, \mathrm{EtOH}\right)$ and aprotic-polar solvents $\left(\mathrm{CH}_{3} \mathrm{CN}\right.$ and acetone, Figure 2, Table 1). In water, the absorption essentially resembles the one of the parent naphthoquinolizinium ion, namely a structured absorption band was observed with a longwavelength absorption maximum at $398 \mathrm{~nm}$ [45]. In all other tested solvents, this absorption band was also observed, however, in some cases less structured, along with an additional very broad red-shifted absorption band with maxima ranging from $447 \mathrm{~nm}(\mathrm{EtOH})$ to $465 \mathrm{~nm}(\mathrm{MeCN})$. The emission intensity of naphthoquinolizinium 2 is weak in water, $\mathrm{MeOH}$, EtOH or acetone $\left(\Phi_{\mathrm{fl}} \leq 0.02\right)$, whereas the emission quantum yield in acetonitrile is significantly higher $\left(\Phi_{\mathrm{fl}}=0.34\right)$. The positions of the emission maxima do not change largely with the solvent and lie between $450 \mathrm{~nm}(\mathrm{EtOH})$ and $459 \mathrm{~nm}(\mathrm{MeOH})$. Most notably, in water a pronounced dual fluorescence was observed with distinct emission maxima at $442 \mathrm{~nm}$ and $562 \mathrm{~nm}$.

Table 1: Absorption and emission properties of the naphthoquinolizinium bromide 2.

\begin{tabular}{lllll} 
Solvent & $\lambda_{\mathrm{abs}}{ }^{\mathrm{a}} / \mathrm{nm}$ & $\lg \varepsilon^{\mathrm{b}}$ & $\lambda_{\mathrm{f}} / \mathrm{nm}^{\mathrm{c}}$ & $\Phi_{\mathrm{fl}} / 10^{-2} \mathrm{~d}$ \\
\hline $\mathrm{H}_{2} \mathrm{O}$ & 398 & 4.06 & 442,562 & 0.6 \\
$\mathrm{MeOH}$ & 400 & 4.21 & 459 & 1.5 \\
$\mathrm{EtOH}$ & 402 & 4.24 & 450 & 1.2 \\
$\mathrm{MeCN}$ & 398 & 4.09 & 439 & 34 \\
Acetone & 399 & 4.05 & 454 & 24 \\
\hline
\end{tabular}

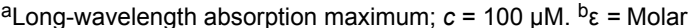
extinction coefficient in $\mathrm{cm}^{-1} \mathrm{M}^{-1}$. ' Fluorescence emission maximum (Abs. $=0.10$ at excitation wavelength). ${ }^{d}$ Fluorescence quantum yield relative to coumarin $1\left(\Phi_{\mathrm{fl}}=0.73\right)$ [46]; in $\mathrm{H}_{2} \mathrm{O}$, MeOH and EtOH quantum yields refer to the combined emission of $\mathbf{2}$ and its deprotonated form $2^{\text {cB }}$; estimated error for $\Phi_{\mathrm{fl}}: \pm 10 \%$ of the given values.

\section{Acid-base titrations}

The dependence of the absorption and emission properties of naphthoquinolizinium derivative $\mathbf{2}$ on the $\mathrm{pH}$ value of the solution was determined with photometric and fluorimetric acid-base titrations in Britton-Robinson buffer at $\mathrm{pH}$ 2.0-10.7 (Figure 3). At pH 2 the quinolizinium 2 exhibits pronounced high-energy absorption bands at $233 \mathrm{~nm}$ and $322 \mathrm{~nm}$ and a long-wavelength absorption band with maxima at $378 \mathrm{~nm}$ and $398 \mathrm{~nm}$. The spectrum remains the same up to a $\mathrm{pH}$ value of ca. 6 (Figure $3 \mathrm{~A}$ ). On further addition of aqueous $\mathrm{NaOH}$ $(\mathrm{pH}>6)$, however, the absorption bands were red shifted by 10-20 nm with significant loss of their band structure. Specifically, a very broad band developed between $400 \mathrm{~nm}$ and $460 \mathrm{~nm}$ with increasing $\mathrm{pH}$. Isosbestic points were formed during the titration at $239 \mathrm{~nm}, 263 \mathrm{~nm}, 328 \mathrm{~nm}$ and $385 \mathrm{~nm}$. The absorption at $\lambda_{\max }=335 \mathrm{~nm}$ was plotted versus the $\mathrm{pH}$ value of the solution, and the experimental data were analysed by a fit to the theoretical model for weak acids (Henderson-Hasselbalch) [47] revealing a $\mathrm{p} K_{\mathrm{a}}$ value of 7.9.

The emission intensity of naphthoquinolizinium derivate $\mathbf{2}$ also depends on the $\mathrm{pH}$ of the aqueous solution (Figure $3 \mathrm{~B}$ ). Namely, both emission bands at $434 \mathrm{~nm}$ and $564 \mathrm{~nm}$ increased with decreasing $\mathrm{pH}$ value of the solution; however, the effect is more pronounced for the short-wavelength emission band at $434 \mathrm{~nm}$. Notably, this development of the blue-shifted emission band continued at strongly acidic conditions, as obtained by the addition of aqueous $\mathrm{HClO}_{4}$ solution. Thus, at very high proton concentration the emission maximum at $434 \mathrm{~nm}$ increased further, whereas the intensity of the long-wavelength band was negligible (cf. Supporting Information File 1, Figure S1).

The absorption and emission properties of derivative $\mathbf{2}$ in $\mathrm{MeOH}$ or MeCN also change drastically upon addition of acid or base (Figure 4 and Figure 5; Supporting Information File 1,
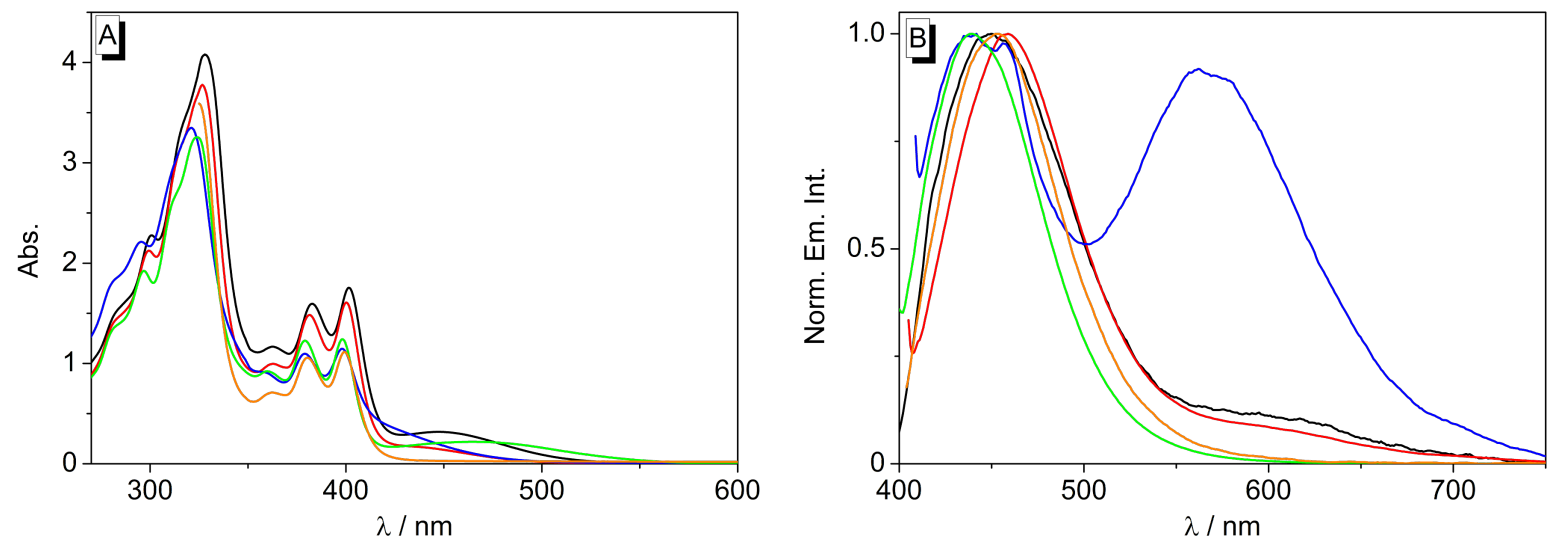

Figure 2: Absorption $(\mathrm{A}, c=100 \mu \mathrm{M})$ and normalized emission spectra $\left(\mathrm{B}, c=10 \mu \mathrm{M}\right.$ or Abs. $=0.1$ at $\left.\lambda_{\mathrm{ex}}\right)$ of derivative 2; solvents: EtOH (black, $\lambda_{\mathrm{ex}}=380 \mathrm{~nm}$ ), $\mathrm{MeOH}\left(\mathrm{red}, \lambda_{\mathrm{ex}}=400 \mathrm{~nm}\right), \mathrm{H}_{2} \mathrm{O}$ (blue, $\lambda_{\mathrm{ex}}=398 \mathrm{~nm}$ ), MeCN (green, $\lambda_{\mathrm{ex}}=398 \mathrm{~nm}$ ), acetone (orange, $\lambda_{\mathrm{ex}}=399 \mathrm{~nm}$ ). 

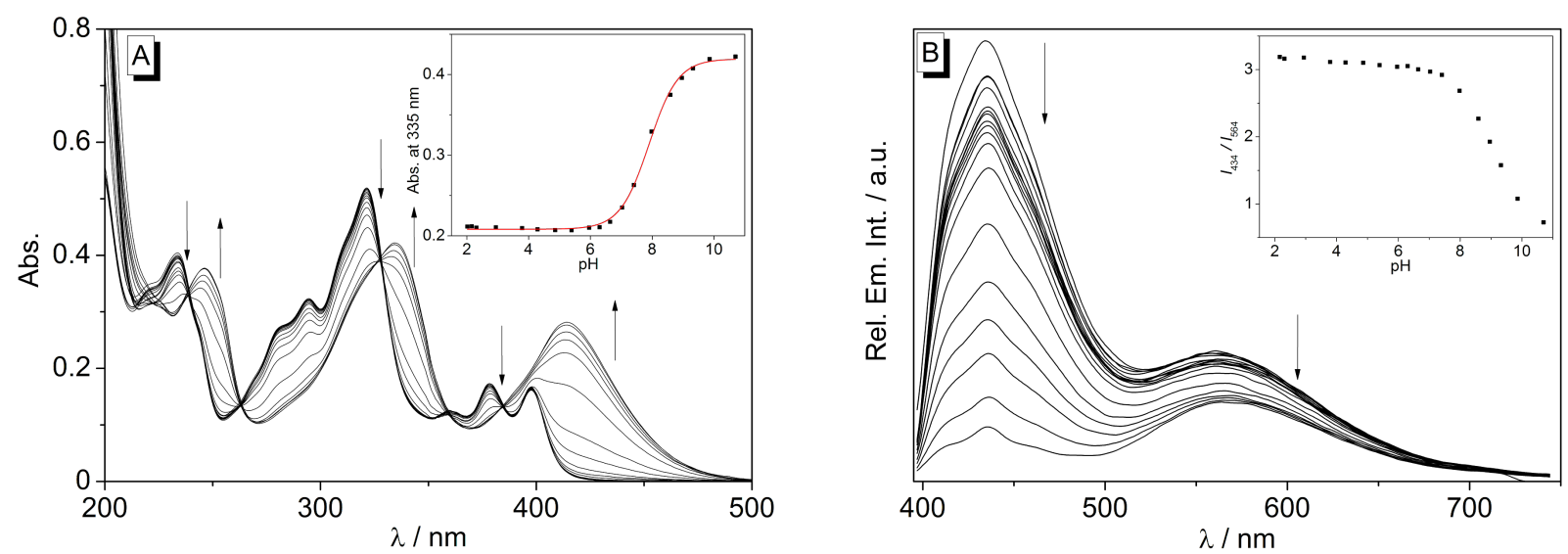

Figure 3: Photometric $(A)$ and fluorimetric $(B)$ acid-base titration $\left(\lambda_{\mathrm{ex}}=380 \mathrm{~nm}\right)$ of naphthoquinolizinium $2(c=15 \mu \mathrm{M})$ in aqueous Britton-Robinson buffer; $\mathrm{pH}$ 2.0-10.7. Arrows indicate the development of bands with increasing pH value of the solution. Insets: Plot of the absorption at $\lambda=335 \mathrm{~nm}$ or ratio of emission intensities, $I_{434} / I_{564}$, versus $\mathrm{pH}$. The red line denotes the best fit of the experimental data to the theoretical isotherm of a weak acid.
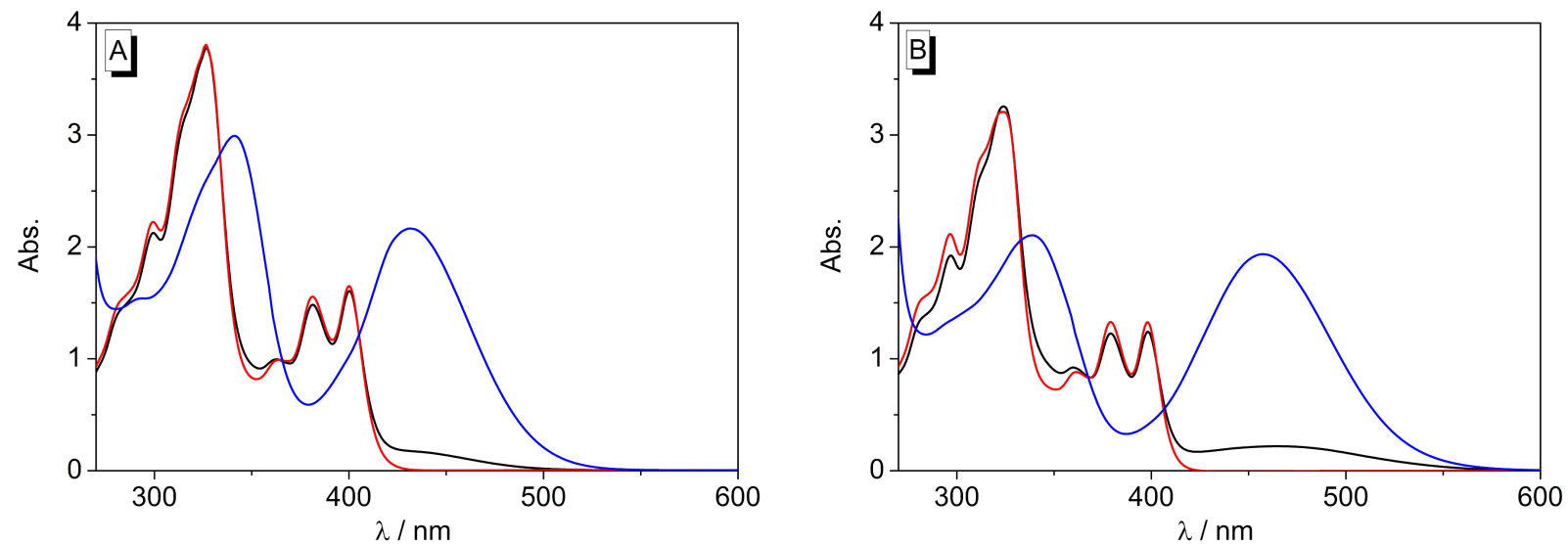

Figure 4: Absorption spectra of $2(c=100 \mu \mathrm{M})$ in $\mathrm{MeOH}(\mathrm{A})$ and $\mathrm{MeCN}(\mathrm{B})$. Black lines: without additive, red: after addition of $\mathrm{CF}_{3} \mathrm{COOH}$, blue: after addition of DBU.
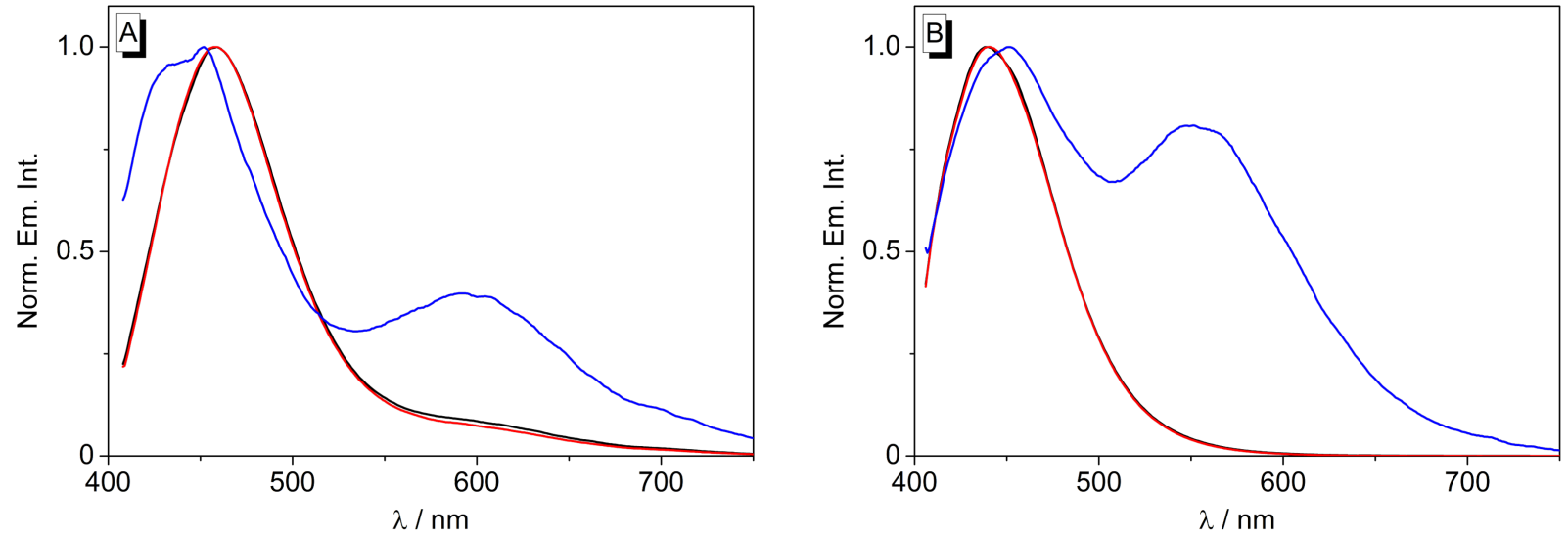

Figure 5: Normalized emission spectra of $2(c=10 \mu \mathrm{M})$ in $\mathrm{MeOH}\left(\mathrm{A}, \lambda_{\mathrm{ex}}=400 \mathrm{~nm}\right)$ and $\mathrm{MeCN}\left(\mathrm{B}, \lambda_{\mathrm{ex}}=398 \mathrm{~nm}\right)$. Black lines: without additive, red: after addition of $\mathrm{CF}_{3} \mathrm{COOH}$, blue: after addition of $\mathrm{DBU}$. 
Figure S2). Upon addition of acid the broad long-wavelength absorption disappears and the more structured absorption band with two local maxima at $381 \mathrm{~nm}$ and $400 \mathrm{~nm}(\mathrm{MeOH})$ or $379 \mathrm{~nm}$ and $398 \mathrm{~nm}(\mathrm{MeCN})$ remains. In contrast, the addition of DBU as a base resulted in the strong increase of the broad absorption band at $431 \mathrm{~nm}$ in $\mathrm{MeOH}$ and at $457 \mathrm{~nm}$ in $\mathrm{MeCN}$.

The emission spectrum of 2 in $\mathrm{MeOH}$ consists of one intense band at $457 \mathrm{~nm}$ upon excitation at $400 \mathrm{~nm}$, along with a very weak red-shifted signal at $600 \mathrm{~nm}$. Upon addition of DBU, the emission is efficiently quenched. The red-shifted emission band, however, develops into a very intense signal on addition of the base to the expense of the blue-shifted band. In $\mathrm{MeCN}$ solution, only the blue-shifted emission band was observed at $438 \mathrm{~nm}$ that increases by a factor of ca. 2 on addition of acid and decreases slightly after addition of base (Supporting Information File 1, Figure S2).

\section{Interactions of 2 with cucurbit[7]uril}

The binding interactions between quinolizinium 2 and $\mathrm{CB}[7]$ were analysed by spectrometric titrations at $\mathrm{pH} 5$ and $\mathrm{pH} 7$ in phosphate buffer solution (Figure 6). Both at $\mathrm{pH} 7$ and 5, the long-wavelength absorption maxima at $322 \mathrm{~nm}, 379 \mathrm{~nm}$ and $398 \mathrm{~nm}$ decreased steadily with a slight red shift and significant line broadening upon addition of a CB[7] solution. Isosbestic points were only maintained during titration at $\mathrm{pH} 5$.

The analysis of the binding isotherms obtained from photometric titrations at $\mathrm{pH} 5$ revealed a 1:1 stoichiometry of 2-CB[7] inclusion complex and a corresponding binding constant of $K_{\mathrm{b}}=1.8 \times 10^{4} \mathrm{M}^{-1}$ (Supporting Information File 1, Figure S5). Unfortunately, the binding constants could not be determined from the titration data at $\mathrm{pH} 7$ due to the complexity of the system resulting from several equilibrium processes. Thus, at $\mathrm{pH}>6$ the deprotonation of ligand 2 starts that - together with the host-guest equilibria - makes the system too complex for the quantitative analysis.

The addition of $\mathrm{CB}$ [7] also affected the emission properties of ligand 2 (Supporting Information File 1, Figure S3). Specifically, the two emission maxima at $434 \mathrm{~nm}$ and $571 \mathrm{~nm}$ decreased, both at pH 7 and 5, without a shift of the emission maxima. As a general trend, the long-wavelength emission at $571 \mathrm{~nm}$ was quenched to a lesser extent.

To assess the influence of the association of the ligand $\mathbf{2}$ with $\mathrm{CB}[7]$ on its acidity, photometric and fluorimetric acid-base titrations were performed with the complex (Figure 7). Such as in the case of the unbound ligand, the absorption bands were red shifted with increasing $\mathrm{pH}$, and a very broad emission band was formed between $400 \mathrm{~nm}$ and $460 \mathrm{~nm}$ at high $\mathrm{pH}$ values. Isosbestic points were not formed during the titration. The data of the photometric titration were employed to determine a $\mathrm{p} K_{\mathrm{a}}$ value of 9.7. The emission of the short-wavelength emission band of the CB[7]-complexed ligand $\mathbf{2}$ is continuously quenched with increasing $\mathrm{pH}$. In contrast, the red-shifted emission at ca. $530 \mathrm{~nm}$ is firstly quenched until a $\mathrm{pH}$ of 8.7 is reached, but it regains intensity at higher $\mathrm{pH}$ values. Unfortunately, titrations had to be stopped at a $\mathrm{pH}$ of ca. 12 because of the base induced ring-opening of the quinolizinium core that occurs at higher $\mathrm{pH}$ values [48].

The excited-state acidity of quinolizinium 2, as quantified by the $\mathrm{p} K_{\mathrm{a}}{ }^{*}$ value, in the absence and presence of $\mathrm{CB}$ [7] was estimated from the absorption and emission data according to the Förster cycle analysis (Equation 1) [49].
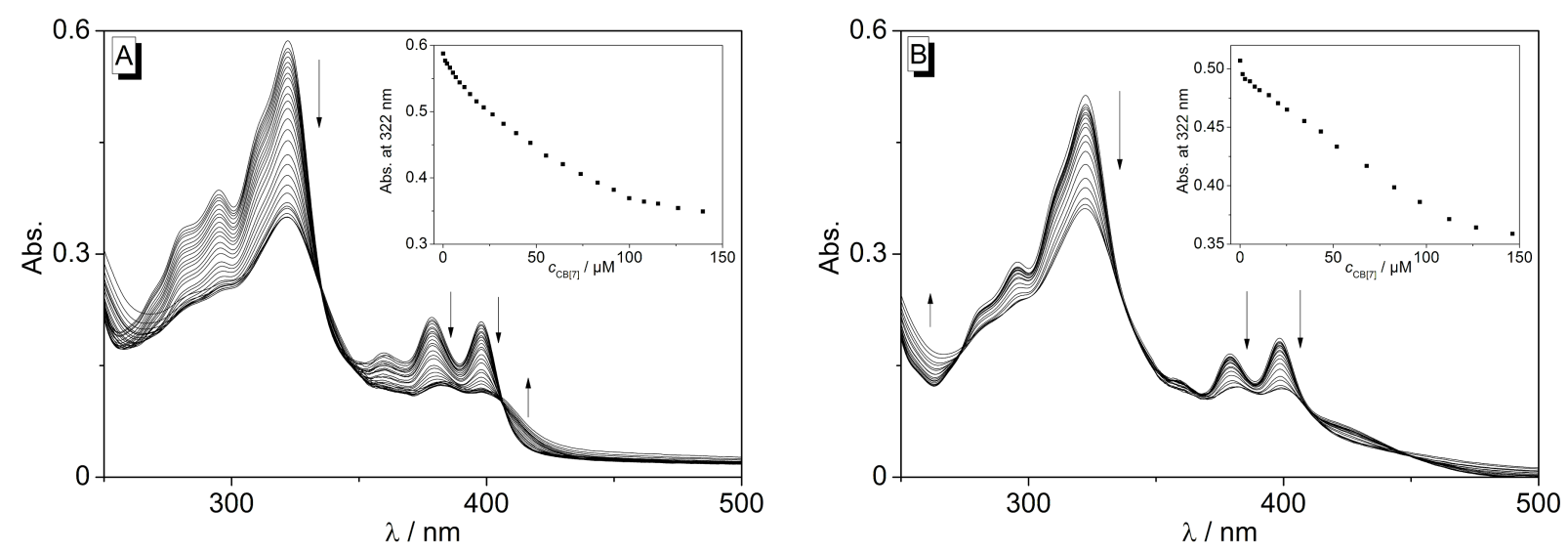

Figure 6: Photometric titration of $\mathrm{CB}[7](c=0.45 \mathrm{mM})$ to $2(c=15 \mu \mathrm{M})$ in $\mathrm{BPE}$ buffer (with $10 \% \mathrm{v} / \mathrm{v} \mathrm{DMSO})$ at $\mathrm{pH} 5(\mathrm{~A})$ and $\mathrm{pH} 7(\mathrm{~B})$. Arrows indicate the development of bands with increasing concentration of $\mathrm{CB}[7]$. Insets: Plot of the absorption at $\lambda=322 \mathrm{~nm}$ versus concentration of $\mathrm{CB}[7]$. 

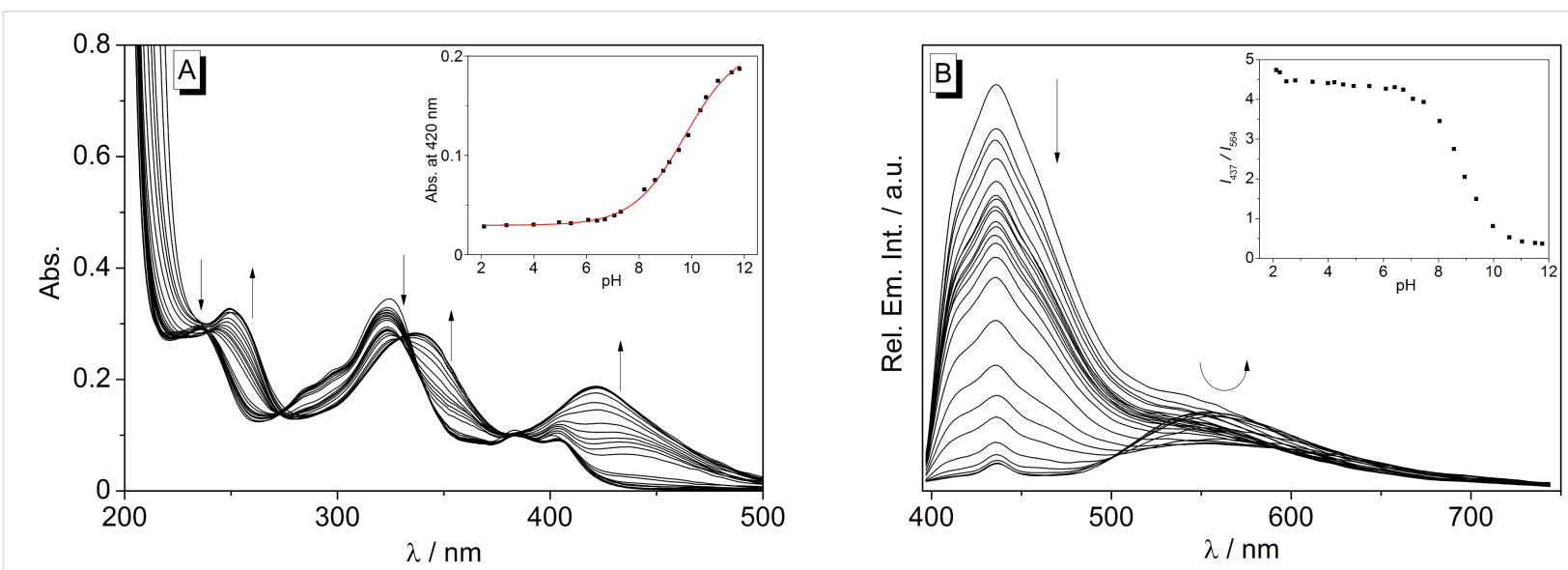

Figure 7: Photometric (A) and fluorimetric $(B)$ acid-base titration $\left(\lambda_{e x}=380 \mathrm{~nm}\right)$ of $2(c=15 \mu \mathrm{M})$ in the presence of $\mathrm{CB}[7](c=100 \mu \mathrm{M})$ in aqueous Britton-Robinson buffer; $\mathrm{pH}$ 2.1-11.8. Arrows indicate the development of bands with increasing $\mathrm{pH}$ value of the solution. Insets: Plot of the absorption at $\lambda=420 \mathrm{~nm}$ or ratio of emission intensities, $I_{437} / I_{564}$, versus $\mathrm{pH}$. The solid line denotes the best fit of the experimental data to the theoretical isotherm of a weak acid.

$$
\Delta \mathrm{p} K_{\mathrm{a}}=0.00209\left[\tilde{\mathrm{v}}\left(\mathbf{2}^{\mathbf{c B}}\right)-\tilde{\mathrm{v}}(\mathbf{2})\right] / \mathrm{cm}^{-1}
$$

In Equation $1 \tilde{v}\left(\mathbf{2}^{\mathbf{c B}}\right)$ and $\tilde{v}(\mathbf{2})$ are the energies of the $0-0$ transitions of the conjugate base $\mathbf{2}^{\mathbf{C B}}$ and the corresponding hydroxyarene $\mathbf{2}$ in wavenumbers as determined from the absorption and emission spectra (cf. Supporting Information File 1, Figure S4). According to this simplified model, the $\mathrm{p} K_{\mathrm{a}}{ }^{*}$ of 2 was calculated as 0.4 , whereas in the presence of $\mathrm{CB}$ [7] it was determined to be $\mathrm{p} K_{\mathrm{a}}{ }^{*}=2.8$.

\section{Discussion}

In analogy to the results reported for 8-hydroxybenzoquinolizinium (1a) [35] the photometric acid-base titrations indicate an equilibrium between hydroxynaphthoquinolizinium $\mathbf{2}$ and its conjugate base $\mathbf{2}^{\mathbf{c B}}$ (Scheme 2). The $\mathrm{p} K_{\mathrm{a}}$ value of 7.9 lies in the expected range for an electron-deficient hydroxyarene and is also comparable to the one of derivative 1a [35]. Notably, the isosbestic points confirm the exclusive presence of the two absorbing species $\mathbf{2}$ and $\mathbf{2}^{\mathbf{c B}}$ in the prototropic equilibrium. Based on the absorption and emission spectra in aqueous buffer, methanol and acetonitrile solution upon addition of acid or base, the blue-shifted absorption and emission bands, that essentially resemble the ones of the parent compound [45], are assigned to hydroxynaphthoquinolizinium 2. In turn, the strongly redshifted broad absorption and emission bands correspond to the conjugate base $\mathbf{2}^{\mathbf{c B}}$. The red-shifted absorption of $\mathbf{2}^{\mathbf{c B}}$ is the result of the formation of the strongly electrondonating oxyanion functionality that leads to a pronounced donor-acceptor interplay with the quinolizinium core in a merocyanine-type conjugation (Scheme 2). A similar effect was postulated for the structurally resembling hydroxystyrylquinolizinium derivatives, such as 6 (Figure 8), that also show a red shift of the absorption upon deprotonation, although to a larger extent (from 405 to $472 \mathrm{~nm}$ ) [50-52]. Notably, the chromophore of the oxyanion-substituted quinolizinium derivative $\mathbf{2}^{\mathbf{c B}}$ resembles the well-established solvatochromic pyridinium- $N$ phenolate betaine dyes that are employed as polarity probes [53]. Correspondingly, the derivative $\mathbf{2}^{\mathbf{c B}}$ shows a similar positive solvatochromism, i.e., a blue shift of the absorption maximum with increasing solvent polarity $\left(\mathrm{CH}_{3} \mathrm{CN}: 457 \mathrm{~nm}\right.$, $\mathrm{MeOH}: 432 \mathrm{~nm}, \mathrm{H}_{2} \mathrm{O}: 415 \mathrm{~nm}$ ).

The prototropic equilibrium between $\mathbf{2}$ and $\mathbf{2}^{\mathbf{c B}}$ is significantly shifted to the deprotonated form $\mathbf{2}^{\mathbf{c B}}$ in the excited state, as commonly observed for hydroxy-substituted arenes. As a result, the $\mathrm{p} K_{\mathrm{a}}{ }^{*}$ of $\mathbf{2}$ is slightly larger than 0 , so that this compound is a representative of the regime I of photoacids [25] whose acidity<smiles>CC(C)C(C)C</smiles> 

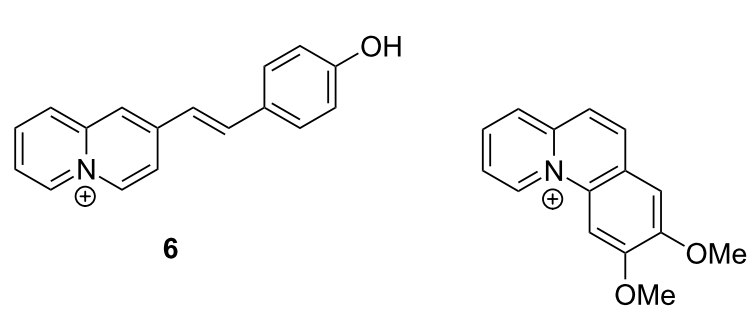

7<smiles>[R12]C(C)=[R]([H])C</smiles>

Figure 8: Structures of quinolizinium derivatives 6-8.

in the excited-state is strong enough to protonate water; as clearly demonstrated by the appearance of the pronounced redshifted emission band of the conjugate base $2^{\mathbf{c B}}$ in this solvent even under neutral conditions.

The quinolizinium-type ligands $\mathbf{1 b}, \mathbf{c}$ and $\mathbf{7}$ were already shown to bind to $\mathrm{CB}[7]$ [36,37]. Accordingly, the naphthoquinolizinium 2 also associates with this host molecule. As a result, the photometric and fluorimetric titrations with $\mathrm{CB}$ [7] show the typical signature of a complex formation, namely a hypochromic effect and red shift of the absorption as well as fluorescence quenching upon addition of the host (Figure 6 and Supporting Information File 1, Figure S3). Furthermore, the significant line broadening of the absorption bands occurs most likely due to restrictions of the molecular movement of the guest ligand provided by confinement of the latter inside the host cavity. Nevertheless, the titrations show that the binding process depends on the $\mathrm{pH}$ of the solution (Figure 7), indicating the interference of the prototropic equilibrium (see below) with the host-guest association. Thus, the titration curve at $\mathrm{pH} 5$ reveals the association of 2 with $\mathrm{CB}$ [7] to result in only one absorbing complex, as clearly indicated by the formation of an isosbestic point. At $\mathrm{pH} 7$, however, no isosbestic points are formed, presumably because of already considerable deprotonation of the ligand at this $\mathrm{pH}$.

The analysis of the binding isotherm ( $\mathrm{pH} 5)$ gave a binding constant $K_{\mathrm{b}}=2 \times 10^{4} \mathrm{M}^{-1}$ that is significantly lower than the ones observed for the benzo[b]quinolizinium derivatives $\mathbf{1 b}$ and $\mathbf{1 c}$ $\left(\approx 10^{8} \mathrm{M}^{-1}\right)$ [37], but comparable to the $K_{\mathrm{b}}$ value of the benzo[c] quinolizinium derivative $7\left(K_{\mathrm{b}}=3 \times 10^{4} \mathrm{M}^{-1}\right)$ [36]. Although a comparison of binding constants from different studies has to be done carefully due to the different experimental conditions, it appears that linear acene-type quinolizinium derivatives fit better into the binding site of $\mathrm{CB}[7]$ with highly favorable energetic interactions, whereas the linear phene-type derivatives bind with lesser, but still significant affinity. Considering the size of the cucurbituril host, it may be assumed that the angular molecules experience steric repulsion with the outer-rim carbonyl groups, which does not occur with the linear molecules that can thread nicely into the binding site. Notably, the structurally resembling alkaloids berberine (8a) and palmatine $(\mathbf{8 b})$, that contain an angularly annelated quinolizinium unit, also bind to $\mathrm{CB}[7]$. But whereas palmatine (8b) has essentially the same binding constant as $2\left(K_{\mathrm{b}}=4.3 \times 10^{4} \mathrm{M}^{-1}\right.$, in phosphate buffer) [39], berberine has a significantly higher affinity $\left(K_{\mathrm{b}}=4.2 \times 10^{5} \mathrm{M}^{-1}\right.$, in phosphate buffer) [40]; although both complexes are proposed to have nearly the same structure. The origin of these inconsistent data has not been assessed or discussed so far. But these observations suggest that the binding constants of complexes between cationic ligands and cucurbiturils depend not only on the actual fit of the ligand to the host structure. In this particular case, the stabilization/ destabilization of the free ligand in water, and for that matter the hydrophobic effect, may influence the equilibrium to a different extend depending on the ligand structure [54].

Remarkably, the $\mathrm{p} K_{\mathrm{a}}$ and $\mathrm{p} K_{\mathrm{a}}{ }^{*}$ values of compound $\mathbf{2}$ increase by about two to three orders of magnitude, respectively, when bound to $\mathrm{CB}$ [7]. Although the change of ground state $\mathrm{p} K_{\mathrm{a}}$ values of acids on association with cucurbituril hosts is well known [16], rather few examples are known whose excitedstate acidity is affected by the formation of inclusion complexes [28-34]. Remarkably, among the latter, examples of photoacidic hydroxyarenes are rather rare. For example, it was shown that the $\mathrm{p} K_{\mathrm{a}}{ }^{*}$ of a hydroxyphenylbenzimidazole and a topotecan derivative increases from 2 to 4 [32] and from -3 to 6 [31], respectively, upon migration from water solution into $\mathrm{CB}$ [7]. In contrast, it was demonstrated that the photoacidity of 2-naphthol is completely suppressed when it is complexed to $\mathrm{CB}$ [7] because the hydroxy functionality is deeply embedded in the host cavity, so that it is no longer available [28].

Hence, hydroxynaphthoquinolizinium 2 is one of the few reported examples of a photoacid whose acidity decreases upon association with $\mathrm{CB}[7]$. In analogy to the behavior of reported 
$\mathrm{CB}[7]$-bound photoacids, it is assumed that the increase of the $\mathrm{p} K_{\mathrm{a}}$ and $\mathrm{p} K_{\mathrm{a}}{ }^{*}$ values originates from the interaction of the acidic functionality with the carbonyl groups at the outer rim of the host molecule $[34,55]$ and - as shown for cationic ligands from the stabilization of the positive charge by the accommodation in the binding site [29].

\section{Conclusion}

In summary we introduced a novel quinolizinium-based photoacid whose acidity in the ground and excited state can be changed by the association with $\mathrm{CB}[7]$. With this result we demonstrated that in general the acidic functionality as well as the photophysical properties of hydroxyquinolizinium derivatives may be modulated by supramolecular interactions. Considering the ability of this class of compounds to operate as DNAbinding ligands [56] or water-soluble chemosensors [57], we anticipate that the combination of these properties with the potential for modulation by host-guest assembly may widen their versatility as functional dyes.

\section{Experimental General}

The employed fine chemicals (Sigma-Aldrich, Acros or Alfa Aesar) were reagent grade and used without further purification. NMR spectroscopy: Bruker Avance $400\left({ }^{1} \mathrm{H}: 400 \mathrm{MHz},{ }^{13} \mathrm{C}\right.$ : $100 \mathrm{MHz})$ or Varian VNMR-S $600\left({ }^{1} \mathrm{H}: 600 \mathrm{MHz},{ }^{13} \mathrm{C}\right.$ : $150 \mathrm{MHz}$ ); at $25^{\circ} \mathrm{C}$. The chemical shifts are given relative to the solvent peak in ppm (DMSO- $d_{6}:{ }^{1} \mathrm{H}=2.50,{ }^{13} \mathrm{C}=39.5$ ). Absorption spectroscopy: Cary 100 bio spectrophotometer with baseline correction; in quartz cells $(10 \mathrm{~mm} \times 10 \mathrm{~mm})$. Emission spectroscopy: Cary Eclipse spectrophotometer at $20{ }^{\circ} \mathrm{C}$; in quartz cells $(10 \mathrm{~mm} \times 10 \mathrm{~mm})$. Elemental analyses: HEKAtech EUROEA combustion analyzer by $\mathrm{Mr}$. Rochus Breuer (Universität Siegen, Organische Chemie I). ESI mass spectrometry: Finnigan LCQ Deca ( $U=6 \mathrm{kV}$; working gas: Argon; auxiliary gas: Nitrogen; temperature of the capillary: $200{ }^{\circ} \mathrm{C}$ ). Melting points: BÜCHI 545 (BÜCHI, Flawil, CH); uncorrected.

\section{Synthesis}

2-(1,3-Dioxolan-2-yl)-1-[(6-methoxynaphth-2-yl)methyl]pyridinium bromide (5). Under argon-gas atmosphere, a solution of 2-(1,3-dioxolan-2-yl)pyridine (3) [43] (1.83 g, $12.1 \mathrm{mmol}$ ) and 6-methoxy-2-bromomethylnaphthalene (4) [44] $(3.05 \mathrm{~g}, 12.1 \mathrm{mmol})$ in DMSO $(90 \mathrm{~mL})$ was stirred at room temperature for $7 \mathrm{~d}$. The solution was added with thorough stirring to EtOAc $(1 \mathrm{~L})$. The white precipitate was filtered off, washed with EtOAc and recrystallised from $\mathrm{MeOH} / \mathrm{EtOAc}$ to give a white solid (3.03 g, $7.53 \mathrm{mmol}, 62 \%)$; mp 160-162 ${ }^{\circ} \mathrm{C}$; ${ }^{1} \mathrm{H}$ NMR $\left(600 \mathrm{MHz}, \mathrm{DMSO}-d_{6}\right) \delta 3.87\left(\mathrm{~s}, 3 \mathrm{H}, \mathrm{OCH}_{3}\right)$, 4.13-4.16 (m, 4H, $\left.2 \times \mathrm{CH}_{2}\right), 6.17\left(\mathrm{~s}, 2 \mathrm{H}, \mathrm{CH}_{2}\right), 6.63(\mathrm{~s}, 1 \mathrm{H}$, $\mathrm{CH}), 7.21\left(\mathrm{dd},{ }^{4} J=2 \mathrm{~Hz},{ }^{3} J=9 \mathrm{~Hz}, 1 \mathrm{H}, 7-\mathrm{H}\right), 7.38\left(\mathrm{~d},{ }^{4} J=2\right.$
$\mathrm{Hz}, 1 \mathrm{H}, 5-\mathrm{H}), 7.48\left(\mathrm{dd},{ }^{4} \mathrm{~J}=2 \mathrm{~Hz},{ }^{3} J=8 \mathrm{~Hz}, 1 \mathrm{H}, 3-\mathrm{H}\right), 7.84$ (d, $\left.{ }^{3} J=9 \mathrm{~Hz}, 1 \mathrm{H}, 8-\mathrm{H}\right), 7.87$ (br. s, $\left.1 \mathrm{H}, 1-\mathrm{H}\right), 7.89$ (d, ${ }^{3} J=8 \mathrm{~Hz}$, $1 \mathrm{H}, 4-\mathrm{H}), 8.21-8.23\left(\mathrm{~m}, 1 \mathrm{H}, 5^{\prime}-\mathrm{H}\right), 8.35\left(\mathrm{dd},{ }^{4} \mathrm{~J}=2 \mathrm{~Hz},{ }^{3} \mathrm{~J}=\right.$ $\left.8 \mathrm{~Hz}, 1 \mathrm{H}, 3^{\prime}-\mathrm{H}\right), 8.74-8.75\left(\mathrm{~m}, 1 \mathrm{H}, 4^{\prime}-\mathrm{H}\right), 9.16\left(\mathrm{dd},{ }^{4} J=2 \mathrm{~Hz}\right.$, $\left.{ }^{3} J=6 \mathrm{~Hz}, 1 \mathrm{H}, 6{ }^{\prime}-\mathrm{H}\right) ;{ }^{13} \mathrm{C}$ NMR $\left(150 \mathrm{MHz}, \mathrm{DMSO}-d_{6}\right) \delta 55.3$ $\left(\mathrm{OCH}_{3}\right), 60.0\left(\mathrm{CH}_{2}\right), 65.6\left(2 \times \mathrm{CH}_{2}\right), 97.1(\mathrm{CH}), 105.9(\mathrm{C} 5)$, 119.3 (C7), 126.0 (C4), 126.1 (C3'), 127.8 (C3), 127.9 (C1), 128.0 (C8a), 128.5 (C2), 128.6 (C5'), 129.6 (C8), 134.3 (C4a), 147.1 (C4', C6'), 151.9 (C2'), 157.9 (C6); ESIMS m/z (\%): 322 (100) $[\mathrm{M}-\mathrm{Br}]^{+}$; anal. calcd for $\mathrm{C}_{20} \mathrm{H}_{20} \mathrm{NO}_{3} \mathrm{Br}$ : C, 59.71; $\mathrm{H}$, 5.01; N, 3.48; found: C, 59.74; H, 4.95; N, 3.51.

3-Hydroxynaphtho[1,2-b]quinolizinium bromide (2). A solution of $5(6.70 \mathrm{~g}, 16.7 \mathrm{mmol})$ in aq $\mathrm{HBr}(48 \%, 60 \mathrm{~mL})$ was stirred under reflux for $4 \mathrm{~h}$. After cooling to room temperature the reaction mixture was poured into THF $(500 \mathrm{~mL})$, and a yellow solid precipitated. The solid was separated by filtration, washed with THF $(50 \mathrm{~mL})$ and $\mathrm{Et}_{2} \mathrm{O}(50 \mathrm{~mL})$. The product 2 was isolated by column chromatography $\left(\mathrm{SiO}_{2}, \mathrm{CHCl}_{3} / \mathrm{MeOH}\right.$ $\left.4: 1, R_{\mathrm{f}}=0.34\right)$ as a canary yellow microcrystalline solid $(2.65 \mathrm{~g}$, $8.13 \mathrm{mmol}, 49 \%)$; $\mathrm{mp}>330{ }^{\circ} \mathrm{C}$; ${ }^{1} \mathrm{H}$ NMR $(600 \mathrm{MHz}$, DMSO- $\left.d_{6}\right) \delta$ 7.40-7.43 (m, 2H, 2-H, 4-H), 7.93-7.95 (m, 1H, $10-\mathrm{H}), 8.00\left(\mathrm{~d},{ }^{3} J=9 \mathrm{~Hz}, 1 \mathrm{H}, 6-\mathrm{H}\right), 8.04\left(\mathrm{~d},{ }^{3} \mathrm{~J}=9 \mathrm{~Hz}, 1 \mathrm{H}\right.$, $5-\mathrm{H}), 8.13-8.16(\mathrm{~m}, 1 \mathrm{H}, 11-\mathrm{H}), 8.54\left(\mathrm{~d},{ }^{3} \mathrm{~J}=9 \mathrm{~Hz}, 1 \mathrm{H}, 12-\mathrm{H}\right)$, $8.93\left(\mathrm{~d},{ }^{3} \mathrm{~J}=9 \mathrm{~Hz}, 1 \mathrm{H}, 1-\mathrm{H}\right), 9.26\left(\mathrm{~d},{ }^{3} J=7 \mathrm{~Hz}, 1 \mathrm{H}, 9-\mathrm{H}\right), 9.80$ (s, 1H, 13-H), 10.15 (s, 1H, 7-H); ${ }^{13} \mathrm{C}$ NMR (150 MHz, DMSO- $\left.d_{6}\right) \delta 113.3(\mathrm{C} 4), 118.6$ (C13), 118.9 (C2), 119.1 (C6a), 121.8 (C10), 123.7 (C6), 124.9 (C13b), 126.6 (C12), 127.5 (C1), 132.4 (C5), 132.4 (C11), 134.4 (C9), 135.8 (C13a), 136.0 (C4a), 137.3 (C7), 138.8 (C12a), 161.1 (C3); ESIMS m/z (\%): $246(100)[\mathrm{M}-\mathrm{Br}]^{+}$; anal. calcd for $\mathrm{C}_{17} \mathrm{H}_{12} \mathrm{NOBr}$ : C, 62.60; $\mathrm{H}$, 3.71 ; N, 4.29; found: C, 62.32; H, 3.70; N, 4.54.

\section{Absorption and emission spectroscopy}

Solutions were prepared from stock solutions of naphthoquinolizinium $2(c=1.0 \mathrm{mM})$ in $\mathrm{MeOH}$ (spectral grade). For experiments in different solvents, a fraction from the stock solution was evaporated and redissolved in e-Pure ${ }^{\mathrm{TM}}$ water (resistivity $\leq 18 \mathrm{M} \Omega \mathrm{cm})$, Britton-Robinson buffer $\left(\mathrm{H}_{3} \mathrm{PO}_{4}, \mathrm{H}_{3} \mathrm{BO}_{3}\right.$, $\mathrm{NaOAc}, 0.04 \mathrm{M}$ each) [58], or acetonitrile (spectral grade).

The fluorescence quantum yields were determined by standard methods [59] with coumarin $1\left(\Phi_{\mathrm{fl}}=0.73\right.$ in EtOH; $\left.\lambda_{\text {ex }}=380 \mathrm{~nm}\right)[46]$ as a reference.

Photometric and fluorimetric $\mathrm{pH}$ titrations were performed in Britton-Robinson buffer (see above) solution ( $\mathrm{pH} 2.0$, $c=15 \mu \mathrm{M})$, and the $\mathrm{pH}$ value was adjusted by addition of $\mathrm{NaOH}(2 \mathrm{M})$. After each addition step, the $\mathrm{pH}$ and the absorption spectra were determined. The $\mathrm{p} K_{\mathrm{a}}$ values were obtained from plots of absorption at fixed wavelength versus the $\mathrm{pH}$ of 
the solution and numerical fitting of the experimental data to the Henderson-Hasselbalch equation [47].

The acidity in the excited state was quantified by the $\mathrm{p} K_{\mathrm{a}}{ }^{*}$ value as obtained from the absorption and emission spectra of $\mathbf{2}$ and its conjugate base and analysis of the data according to the Förster-cycle [49]. The fully protonated form was obtained by addition of aq $\mathrm{HClO}_{4}$ (concentrations $0.01-11.8 \mathrm{M}$ ) to solutions of 2.

Titration experiments with $\mathrm{CB}$ [7] were carried out in phosphate buffer $\left(6.0 \mathrm{mM} \mathrm{Na} \mathrm{HPO}_{4}, 2.0 \mathrm{mM} \mathrm{NaH} \mathrm{PO}_{4}, 1.0 \mathrm{mM}\right.$ $\mathrm{Na}_{2}$ EDTA; final $\mathrm{Na}^{+}$concentration: $16.0 \mathrm{mM}$; $\mathrm{pH}$ 7.0; $T=25^{\circ} \mathrm{C}$ ). To a constant volume of a solution of the naphthoquinolizinium derivative 2 were titrated small amounts of $\mathrm{CB}[7]$ solution, that contained the same concentration of the ligand as the analyte sample. Absorption and emission were determined after at least 2 min of equlibration time. The data from the titrations were plotted as absorption or emission intensity versus concentration of $\mathrm{CB}[7]$, and the resulting binding isotherms were used to obtain the binding constants $K_{\mathrm{b}}$ with the SpecFit 32 program.

\section{Supporting Information}

\section{Supporting Information File 1}

NMR spectra of compounds $\mathbf{2}$ and $\mathbf{5}$; fluorimetric titrations of 2 with acid and $\mathrm{CB}$ [7]; determination of 0-0 transition energies; analysis of binding isotherms from photometric titrations of 2 with $\mathrm{CB}[7]$.

[http://www.beilstein-journals.org/bjoc/content/ supplementary/1860-5397-13-23-S1.pdf]

\section{Acknowledgements}

This work was generously financed by the Deutsche Forschungsgemeinschaft (IH24/10-1). We thank Ms. Jennifer Hermann and Ms. Sandra Uebach for technical assistance.

\section{References}

1. Schneider, H.-J.; Yatsimirsky, A. Principles and Methods in Supramolecular Chemistry; Wiley: Chichester, 2000.

2. Steed, J. W.; Turner, D. R.; Wallace, K. J. Core concepts in Supramolecular Chemistry and Nanochemistry; Chichester: Wiley, 2007.

3. Cong, H.; Ni, X. L.; Xiao, X.; Huang, Y.; Zhu, Q.-J.; Xue, S.-F.; Tao, Z.; Lindoy, L.; Wie, G. Org. Biomol. Chem. 2016, 14, 4335-4346. doi:10.1039/C6OB00268D

4. Assaf, K. I.; Nau, W. M. Chem. Soc. Rev. 2015, 44, 394-418. doi:10.1039/C4CS00273C

5. Isaacs, L. Chem. Commun. 2009, 619-629. doi:10.1039/B814897J
6. Barrow, S. J.; Kasera, S.; Rowland, M. J.; del Barrio, J.; Scherman, O. A. Chem. Rev. 2015, 115, 12320-12406. doi:10.1021/acs.chemrev.5b00341

7. Dsouza, R. N.; Pischel, U.; Nau, W. M. Chem. Rev. 2011, 111, 7941-7980. doi:10.1021/cr200213s

8. Bibal, B.; Mongin, C.; Bassani, D. M. Chem. Soc. Rev. 2014, 43, 4179-4198. doi:10.1039/c3cs60366k

9. Ramamurthy, V.; Inuoe, Y., Eds. Supramolecular Photochemistry; Wiley: New Jersey, 2011.

10. Parente Carvalho, C.; Domínguez, Z.; Da Silva, J. P.; Pischel, U. Chem. Commun. 2015, 51, 2698-2701. doi:10.1039/C4CC09336D

11. Maddipatla, M. V. S. N.; Pattabiraman, M.; Natarajan, A.; Srivastav, K.; Mague, J. T.; Ramamurthy, V. Org. Biomol. Chem. 2012, 10 , 9219-9222. doi:10.1039/c2ob26743h

12. Yang, C.; Ke, C.; Liang, W.; Fukuhara, G.; Mori, T.; Liu, Y.; Inoue, Y. J. Am. Chem. Soc. 2011, 133, 13786-13789. doi:10.1021/ja202020x

13. Pemberton, B. C.; Singh, R. K.; Johnson, A. C.; Jockusch, S.; Da Silva, J. P.; Ugrinov, A.; Turro, N. J.; Srivastava, D. K.; Sivaguru, J. Chem. Commun. 2011, 47, 6323-6325. doi:10.1039/c1cc11164g

14. Maddipatla, M. V. S. N.; Kaanumalle, L. S.; Natarajan, A.; Pattabiraman, M.; Ramamurthy, V. Langmuir 2007, 23, 7545-7554. doi:10.1021/la700803k

15. Pattabiraman, M.; Kaanumalle, L. S.; Natarajan, A.; Ramamurthy, V. Langmuir 2006, 22, 7605-7609. doi:10.1021/la061215a

16. Thomas, S. S.; Bohne, C. Faraday Discuss. 2015, 185, 381-398. doi:10.1039/C5FD00095E

17. Gavvala, K.; Sengupta, A.; Koninti, R. K.; Hazra, P. J. Phys. Chem. B 2013, 117, 14099-14107. doi:10.1021/jp408280p

18. Tang, H.; Fuentealba, D.; Ko, Y. H.; Selvapalam, N.; Kim, K.; Bohne, C. J. Am. Chem. Soc. 2011, 133, 20623-20633. doi:10.1021/ja209266x

19. Macartney, D. H. Isr. J. Chem. 2011, 51, 600-615. doi:10.1002/ijch.201100040

20. Koner, A. L.; Ghosh, I.; Saleh, N.; Nau, W. M. Can. J. Chem. 2011, 89, 139-147. doi:10.1139/V10-079

21. Shaikh, M.; Mohanty, J.; Singh, P. K.; Nau, W. M.; Pal, H. Photochem. Photobiol. Sci. 2008, 7, 408-414. doi:10.1039/B715815G

22. Praetorius, A.; Bailey, D. M.; Schwarzlose, T.; Nau, W. M. Org. Lett. 2008, 10, 4089-4092. doi:10.1021/ol8016275

23. Saleh, N.; Koner, A. L.; Nau, W. M. Angew. Chem., Int. Ed. 2008, 47, 5398-5401. doi:10.1002/anie.200801054

24. Mohanty, J.; Bhasikuttan, A. C.; Nau, W. M.; Pal, H. J. Phys. Chem. B 2006, 110, 5132-5138. doi:10.1021/jp056411p

25. Simkovitch, R.; Shomer, S.; Gepshtein, R.; Huppert, D. J. Phys. Chem. B 2015, 119, 2253-2262. doi:10.1021/jp506011e

26. Agmon, N. J. Phys. Chem. A 2005, 109, 13-35. doi:10.1021/jp047465m

27. Tolbert, L. M.; Solntsev, K. M. Acc. Chem. Res. 2002, 35, 19-27. doi:10.1021/ar990109f

28. Basílio, N.; Laia, C. A. T.; Pina, F. J. Phys. Chem. B 2015, 119, 2749-2757. doi:10.1021/jp511351w

29. Basarić, N.; Thomas, S. S.; Bregović, V. B.; Cindro, N.; Bohne, C. J. Org. Chem. 2015, 80, 4430-4442. doi:10.1021/acs.joc.5b00275

30. Banik, D.; Kuchlyan, J.; Roy, A.; Kundu, N.; Sarkar, N. J. Phys. Chem. B 2015, 119, 2310-2322. doi:10.1021/jp5064879

31. Gavvala, K.; Sengupta, A.; Koninti, R. K.; Hazra, P. ChemPhysChem 2013, 14, 3375-3383. doi:10.1002/cphc.201300461

32. Shaikh, M.; Choudhury, S. D.; Mohanty, J.; Bhasikuttan, A. C.; Nau, W. M.; Pal, H. Chem. - Eur. J. 2009, 15, 12362-12370. doi:10.1002/chem.200900390 
33. Montes-Navajas, P.; Garcia, H. J. Photochem. Photobiol., A 2009, 204, 97-101. doi:10.1016/j.jphotochem.2009.02.019

34. Wang, R.; Yuan, L.; Macartney, D. H. Chem. Commun. 2005, 5867-5869. doi:10.1039/b513246k

35. Schäfer, K.; Ihmels, H.; Bohne, C.; Valente, K. P.; Granzhan, A. J. Org. Chem. 2016, 81, 10942-10954. doi:10.1021/acs.joc.6b01991

36. Berdnikova, D. V.; Aliyeu, T. M.; Paululat, T.; Fedorov, Y. V.; Fedorova, O. A.; Ihmels, H. Chem. Commun. 2015, 51, 4906-4909. doi:10.1039/C5CC01025J

37. Wang, R.; Yuan, L.; Ihmels, H.; Macartney, D. H. Chem. - Eur. J. 2007, 13, 6468-6473. doi:10.1002/chem.200700199

38. Li, C.-F.; Du, L.-M.; Wu, W.-Y.; Sheng, A.-Z. Talanta 2010, 80, 1939-1944. doi:10.1016/j.talanta.2009.10.049

39. Li, C.; Li, J.; Jia, X. Org. Biomol. Chem. 2009, 7, 2699-2703. doi:10.1039/b820852b

40. Megyesi, M.; Biczók, L.; Jablonkai, I. J. Phys. Chem. C 2008, 112, 3410-3416. doi:10.1021/jp075348w

41. Bradsher, C. K. Chem. Rev. 1946, 38, 447-499. doi:10.1021/cr60121a003

42. Sucunza, D.; Cuadro, A. M.; Alvarez-Builla, J.; Vaquero, J. J. J. Org. Chem. 2016, 81, 10126-10135. doi:10.1021/acs.joc.6b01092

43. Bradsher, C. K.; Parham, J. C. J. Org. Chem. 1963, 28, 83-85. doi:10.1021/jo01036a018

44. McCarthy, J. R.; Huffman, J. C. J. Org. Chem. 1984, 49, 4995-4997. doi:10.1021/jo00199a048

45. Ihmels, H.; Mohrschladt, C. J.; Schmitt, A.; Bressanini, M.; Leusser, D.; Stalke, D. Eur. J. Org. Chem. 2002, 2624-2632. doi:10.1002/1099-0690(200208)2002:15<2624::AID-EJOC2624>3.0.C $\mathrm{O} ; 2-\mathrm{Q}$

46. Jones, G., II; Jackson, W. R.; Choi, C.-Y.; Bergmark, W. R. J. Phys. Chem. 1985, 89, 294-300. doi:10.1021/j100248a024

47. Polster, J.; Lachmann, H. Spectrometric Titrations: Analysis of Chemical Equilibria; VCH: Weinheim, 1989.

48. Krapcho, A. P.; Cadamuro, S. A.; Macnee, L. ARKIVOC 2007, ix, 28-44.

And references cited therein.

49. Weller, A. Z. Elektrochem. 1952, 56, 662-668.

50. Sato, K.; Okabe, Y.; Onitake, T.; Yamaguchi, M.; Arai, S.; Yamagishi, T. Supramol. Chem. 2011, 23, 249-251. doi:10.1080/10610278.2010.521839

51. Arai, S.; Hida, M.; Yamagishi, T. Dyes Pigm. 1995, 29, 263-273. doi:10.1016/0143-7208(95)00052-6

52. Arai, S.; Nakakura, K.; Ishikawa, M.; Hida, M. J. Chem. Soc., Perkin Trans. 1 1990, 1915-1917. doi:10.1039/p19900001915

53. Machado, V. G.; Stock, R. I.; Reichardt, C. Chem. Rev. 2014, 114, 10429-10475. doi:10.1021/cr5001157

54. Davis, A. M.; Teague, S. J. Angew. Chem., Int. Ed. 1999, 38, 736-749. doi:10.1002/(SICI)1521-3773(19990315)38:6<736::AID-ANIE736>3.0. CO;2-R

55. Ghosh, I.; Nau, W. M. Adv. Drug Delivery Rev. 2012, 64, 764-783. doi:10.1016/j.addr.2012.01.015

56. Granzhan, A.; Ihmels, H. Synlett 2016, 27, 1775-1793. doi:10.1055/s-0035-1561445

57. Granzhan, A.; Ihmels, H.; Tian, M. ARKIVOC 2015, vi, 494-523. doi:10.3998/ark.5550190.p009.339

58. Britton, H. T. S.; Robinson, R. A. J. Chem. Soc. 1931, 458-473. doi:10.1039/JR9310000458
59. Lakowicz, J. R. Fluorescence Sensing. Principles of Fluorescence Spectroscopy, 3rd ed.; Springer: New York, 2006; pp 623-674. doi:10.1007/978-0-387-46312-4

\section{License and Terms}

This is an Open Access article under the terms of the Creative Commons Attribution License

(http://creativecommons.org/licenses/by/4.0), which permits unrestricted use, distribution, and reproduction in any medium, provided the original work is properly cited.

The license is subject to the Beilstein Journal of Organic Chemistry terms and conditions:

(http://www.beilstein-journals.org/bjoc)

The definitive version of this article is the electronic one which can be found at: doi: $10.3762 /$ bjoc. 13.23 